\title{
Malaysian Cuisine - A Saleable Brand in Chennai
}

\author{
Charlet Christina Rajakumari R.
}

\begin{abstract}
Malaysia is an integrated society of Malays, Bumiputeras, Chinese and Indian Population, practicing Islam, Buddhism, Christianity, Daoism, Hinduism, Sikhism and Shamanism. Malaysian cuisine is a mixture of Thai, Indian, Chinese and many other cultures. A close analysis reveals that India and Malaysia are quite similar with respect to the traditional values, tribal contributions and obvious food habits. The historical migrations from India to Malaysia in the 19th century and the geographical advantage of Malaysia has resulted in similar eating habits and symphony of flavours. In spite of the similarities Malaysian food is not well accepted by the Chennai population. The facts of the Chennai dining industry show that Chinese, American, European and Italian cuisines are more popular in Chennai rather than Malaysian cuisine. Therefore an attempt to derive a formula for success of Malaysian restaurants in Chennai is undertaken in this research.
\end{abstract}

Index Terms-Customer perception, India, Malaysia, marketing strategies, restaurants.

\section{INTRODUCTION}

Malaysia is an integrated society of Malays, Bumiputeras, Chinese and Indian Population, practicing Islam, Buddhism, Christianity, Daoism, Hinduism, Sikhism and Shamanism. Though the traditional Bahasa Malaysia is the national language and is widely spoken, the urban population of Malaysia have started using English and Malay slang words in their everyday communication. Malaysia has acquired traditional dance forms that originated from India, Portuguese and Thai. Malaysian cuisine is a mixture of Thai, Indian, Chinese and many other cultures. A close analysis reveals that India and Malaysia are quite similar with respect to the traditional values, tribal contributions and obvious food habits. The historical migrations from India to Malaysia in the $19^{\text {th }}$ century and the geographical advantage of Malaysia has resulted in similar eating habits and symphony of flavours. Both Indians and Malaysians have a love towards food in the way it is cooked. They enjoy hot food with lots of spices and relish rice with sea food. Foods of Indian origin including rice, roti, dosai, idly dominate Malaysian cuisine. Both kitchens use tamarind paste, coconut milk and spices like cardamom, turmeric, cinnamon, cloves, cumin seeds, curry leaves etc. in day to day cooking.

After learning these similarities shared between India and Malaysia, one tends to think that both countries accept and appreciate the food culture of one another. But the facts of the Chennai dining industry show that Chinese, American, European and Italian cuisines are more popular in Chennai

Manuscript received January 1, 2014; revised March 3, 2014.

Charlet Christina Rajakumari R. is with the Department of Commerce, Madras Christian College, Chennai, Tamilnadu, India (e-mail: charlet.mcc@gmail.com). rather than Malaysian cuisine. Hence the researcher is motivated to study the attitude of Chennai population towards Malaysian food and suggest ideas for making Malaysian cuisine saleable in Chennai.

\section{REVIEW OF LiterATURE}

1) Multinational fast food franchisees adopt advanced styles of marketing strategies like segmentation, targeting, positioning etc., when compared to Indian fast food franchisees. MNCs' follow demand based, competition based and geographical pricing policy but Indian restaurants mostly fix their price based on competition. Aggressive advertising and customer relationship management are the reasons for success of multinational fast food franchisees [1].

2) The Chinese retailers specifically analyze the customers' buying behavior and structure their positioning strategies considering the attitudes and buying behavior of the customers. This has resulted in huge sales in the up market stores in China [2].

3) Indian market is well catered well with ready to eat food like pizzas, burgers, hot dogs etc., by the American, Italian and Chinese outlets. The demand for American, Chinese and Italian food style is ever increasing due to convenience, lack of time for cooking, change in life style etc [3].

4) Organized retail outlets can capitalize on the spending power of the nuclear urban families in India who have divergent tastes and unique needs. Hence hotel retailers can profit from an organized franchise model that has an in built objective of reduced cost of rent and human resource [4].

5) The Americans who had knowledge about Hansik (Korean food) have tried Korean food. The attitude towards Hansik urged the Americans not only to try Hansik but also motivated them to visit Korea at least once [5].

6) International brands decide to franchise their outlets in India due to direct stimuli, background and demographic factors of the decision maker. International brands offer superior service quality when compared to the Indian brands [6].

7) There is no significant difference in the behavior of different aged male and female customers. All customers look out for good standardized hotels, safety and cleanliness in restaurants [7].

8) Food industry grows rapidly since the financial risk is very low. Uncertain market conditions must be considered and analysed while expanding operations from one country to another [8].

9) Emotions and memorable experience in a hotel enhances 
satisfaction, improves retention, results in positive word of mouth and helps in creating and maintaining good relationship between customer and the employees and thereby increases customer loyalty [9].

10) Variety drives the customers to experimenting new restaurants and new types of food. Boredom strikes a customer when he visits the same restaurant time and again. The managers should keep introducing variety in their menu. New interiors, change in wall pictures, advertising style can create a new mood when the customers come back to the same restaurant [10].

\section{OBJECTIVES OF THE STUDY}

1) To study the attitude of Chennai population towards Malaysian food.

2) To analyze the mind blocks of Chennai population in trying Malaysian food.

3) To derive a formula for success of Malaysian restaurants in Chennai.

\section{Methodology}

\begin{tabular}{|l|l|l|}
\multicolumn{2}{l}{ TABLE I: SAMPLE SIZE } \\
\begin{tabular}{|l|l|l|}
\hline Cases & $N$ & $\%$ \\
\hline Valid & 200 & 100.0 \\
\hline Excluded & 0 & .0 \\
\hline Total & 200 & 100.0 \\
\hline
\end{tabular}
\end{tabular}

A sample of 200 people from the population of Chennai was randomly interviewed and their responses were collected by way of printed questionnaires. The data thus obtained was analyzed using statistical tools namely Frequency, Cross-Tabs, Chi-Sq., ANOVA and Factor Analysis. The results were interpreted, inferences were drawn and presented in the findings.

\section{HYPOTHESIS}

1) "There is no significant difference between the attitudes of young and older people towards Malaysian cuisine".

2) "There is no significant difference between the attitudes of men and women towards Malaysian cuisine".

3) "There is no association between the type of occupation and the hesitation to try Malaysian food".

4) "There is no association between the marital status and the hesitation to try Malaysian food".

\section{DISCUSSION}

The sample studied included men and women belonging to different age groups both married and un- married working in different organizations and practicing various professions in Chennai. All classes of the society drawing high, average and low level of salaries were considered for the survey. The majority of the respondents were married men of $26-35$ years working in the IT sector earning from 15000-30000.
TABLE II: DEMOGRAPHICS

\begin{tabular}{|c|c|c|}
\hline Demographics & Group & Freq. \\
\hline \multirow[t]{5}{*}{ Age } & $15-25$ & 54 \\
\hline & $26-35$ & 72 \\
\hline & $36-45$ & 29 \\
\hline & $46-60$ & 36 \\
\hline & Above 60 & 9 \\
\hline \multirow[t]{2}{*}{ Gender } & Male & 109 \\
\hline & Female & 91 \\
\hline \multirow[t]{8}{*}{ Occupation } & Government & 11 \\
\hline & Non - Government & 55 \\
\hline & Software & 80 \\
\hline & Business & 5 \\
\hline & Professional & 24 \\
\hline & Retired & 1 \\
\hline & Student & 21 \\
\hline & Unemployed & 3 \\
\hline \multirow[t]{4}{*}{ Monthly Income } & Less than 15000 & 53 \\
\hline & 15001 - 30000 & 96 \\
\hline & $30001-45000$ & 30 \\
\hline & Above 45000 & 21 \\
\hline \multirow[t]{2}{*}{ Marital Status } & Married & 107 \\
\hline & Single & 93 \\
\hline
\end{tabular}

TABLE III: RELIABILITY STATISTICS

\begin{tabular}{|l|l|}
\hline Cronbach's Alpha & $N$ of Items \\
\hline $\mathbf{0 . 7 0 8}$ & 44 \\
\hline
\end{tabular}

The reliability test showed a Cronbach's Alpha value of $0.708(>0.5)$ which denotes that the data can be commended as highly reliable.

TABLE IV: NUMBER OF RESPONDENTS WHO KNOW THAT THE GIVEN RESTAURANTS ARE MALAYSIAN

\begin{tabular}{|l|l|}
\hline Restaurant & Frequency (out of 200) \\
\hline Pelita Nasi Kandar & 79 \\
\hline Dim Sum & 35 \\
\hline Her Name is Ming & 36 \\
\hline Momo Restaurant & 42 \\
\hline Hotel Malaysian Inn & $\mathbf{1 6 8}$ \\
\hline L'attitude 49 & 31 \\
\hline Night Queen & 38 \\
\hline
\end{tabular}

TABLE V: NUMBER OF RESPONDENTS WHO KNOW THAT THE GIVEN FOOD IS MALAYSIAN

\begin{tabular}{|l|l|}
\hline Food & Frequency (out of 200) \\
\hline Nasi Kandar & $\mathbf{8 3}$ \\
\hline Nasi Dagang & 69 \\
\hline Bakuteh & 46 \\
\hline Hokkien Mee & 47 \\
\hline Sang Har Noodles & 35 \\
\hline Char Siew Rice & 31 \\
\hline Nasi Lamek & 67 \\
\hline
\end{tabular}

Table IV and Table V show that the Chennai population is completely ignorant about Malaysian restaurants in Chennai and Malaysian food. Only about one - fourth of the population knew that the stated restaurants and foods belonged to the Malaysian origin. It's obvious that one identifies the Hotel Malaysian Inn to be Malaysian since the name implies so. This proves the fact the name of the restaurant has an impact in the identity of the restaurant.

\section{A. Perception about Taste of Malaysian Food}

Fig. 1 depicts the perception of the Chennai population about the taste of Malaysian food. Most of them believe it to be raw and semi cooked having a combination of sour and sweet flavor. Some feel that Malaysian food would be bland 
and tasteless. Only a few realize that Malaysian food is actually hot and spicy. This once again proves that Chennai population has no idea about Malaysian food.

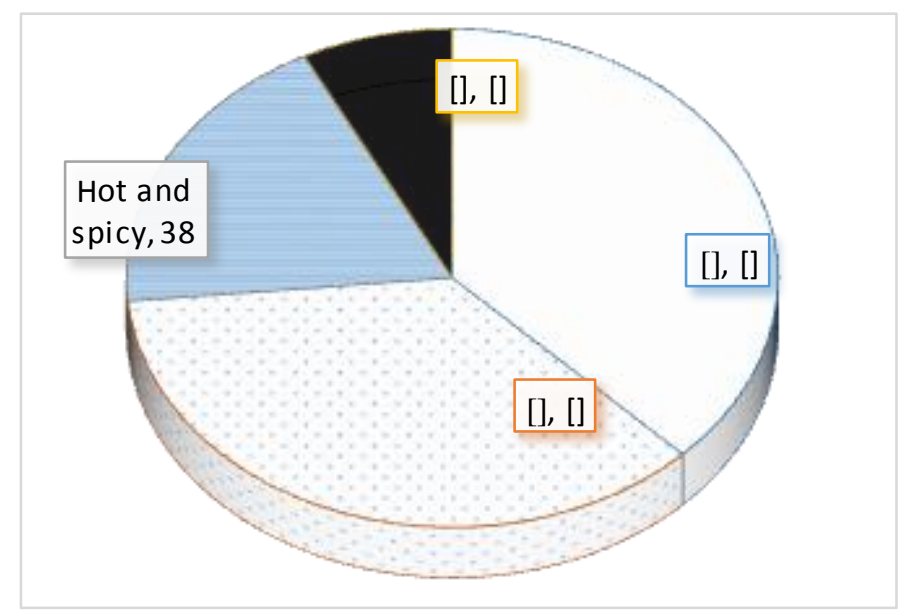

Fig. 1. Taste of Malaysian food.

\section{B. Number of Respondents Who Have Tasted Malaysian Food}

Fig. 2 shows that less than a quarter of the Chennai population has ever gone to a Malaysian restaurant or even tasted Malaysian food in any restaurant. It's right to say that Malaysian food is unpopular in Chennai.

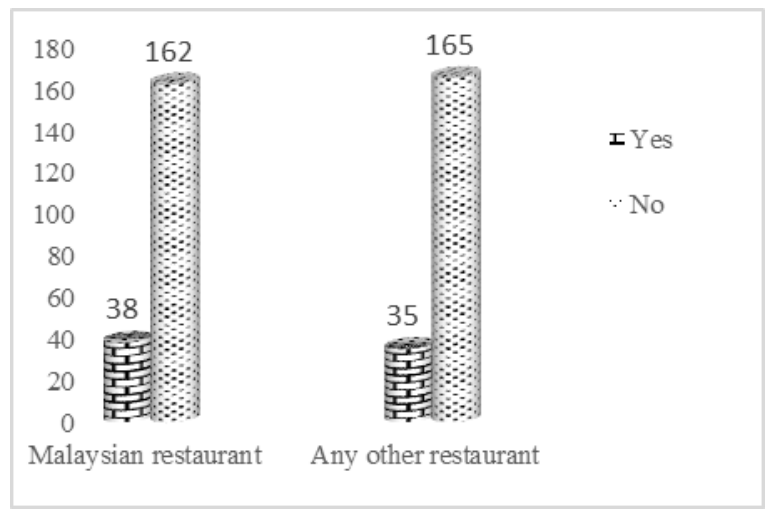

Fig. 2. Tasted Malaysian food.

\section{Reasons for not Visiting Malaysian Restaurants}

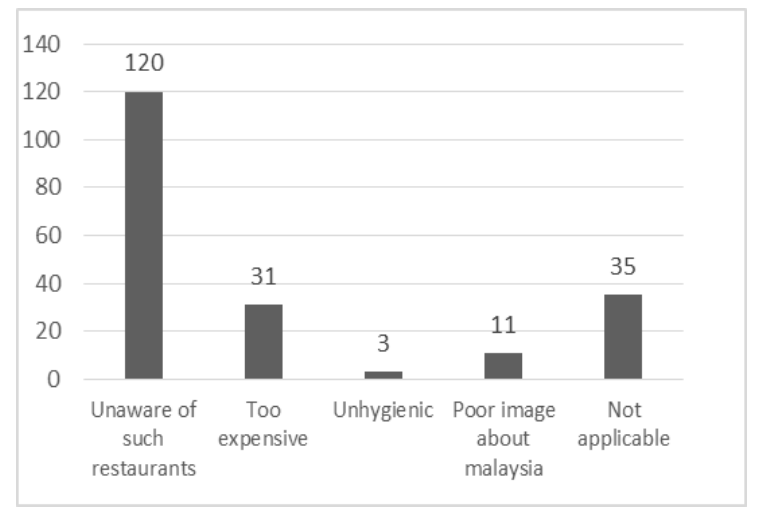

Fig. 3. Reasons for not visiting Malaysian restaurants.

\section{Reason for Not Trying Malaysian Food}

When the respondents were interviewed about the reasons for not visiting Malaysian restaurants and trying such food the common response was "is such a place there in Chennai?"
This response describes the ignorance of the Chennai population with respect to the Malaysian food and the places where it's available.

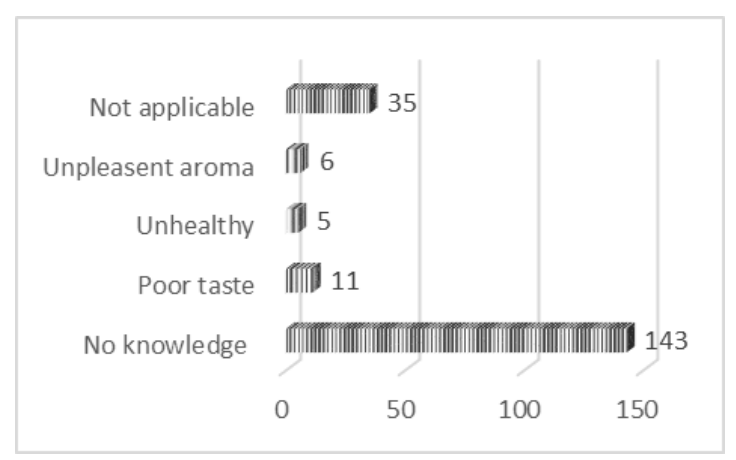

Fig. 4. Reasons for not trying Malaysian food.

\section{E. Willingness to Try Malaysian Food Free of Cost}

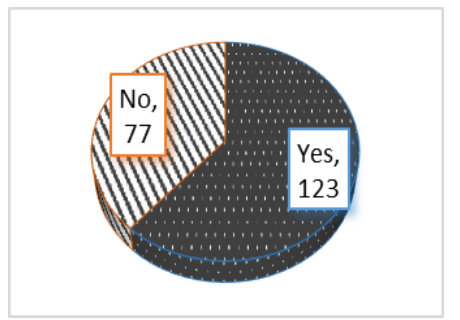

Fig. 5. Willingness to try Malaysian food for free.

Though the Chennai people are unaware of Malaysian food, their minds are not closed towards trying it. Though few people have an aversion towards Malaysian food nearly three - fourths of the population is ready to try it for the first time. This throws a huge scope for capturing Chennai market with Malaysian food.

\section{F. Factors Considered While Choosing a Restaurant}

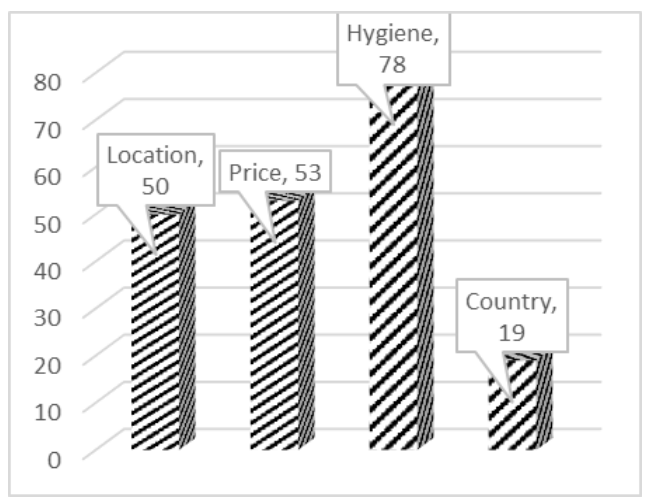

Fig. 6. Factors considered.

Universally hygiene is the most important feature that a customer looks for in a restaurant. Though location and price play significant part in narrowing down to a particular restaurant, hygiene continues to be the most important concern of the Chennai people in deciding the restaurant to pop in.

\section{G. Necessity of Tamil / English in the Restaurant}

Only a negligible percentage of the respondents are ok with Malaysian names, menu cards with no English/ Tamil 
explanations and bearers with less fluency in English/ Tamil. Most of them feel that a Tamil or an English name is necessary to enable them to identify a Malaysian restaurant and they also demand that the menu card must have a clear explanation of every dish in English/ Tamil so that they can choose what they actually want to eat. Chennai population is more comfortable in placing orders with a tamilian who speaks good Tamil and English than a Chinese or a Malaysian who do not understand what the customer expects. It can be inferred from the above facts that the best manner to motivate a person in Chennai to visit a Malaysian restaurant is by naming the restaurant in Tamil or English, having menu cards with understandable explanations and employing Tamilians in the restaurant.

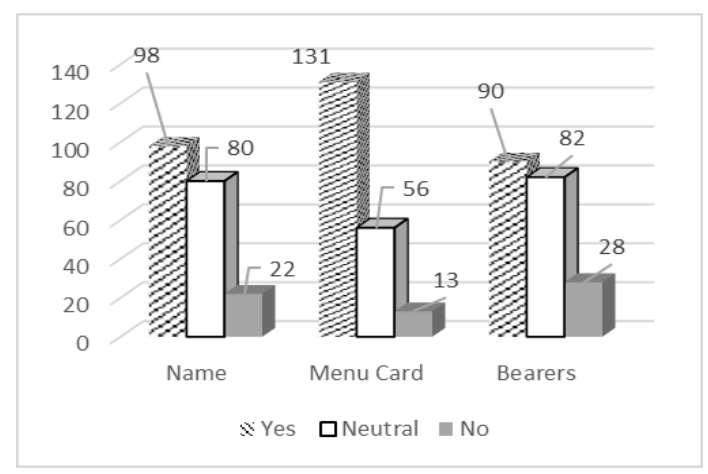

Fig. 7. Necessity of Tamil / English.

Number of respondents willing to try Malaysian restaurants when the following features are promised (out of 200)

TABLE VI: WILLINGNESS TO VISIT MALAYSIAN RESTAURANT

\begin{tabular}{|l|l|l|l|}
\hline Willingness & Yes & May Be & No \\
\hline Publicized & $\mathbf{9 4}$ & 78 & 28 \\
\hline Hot \& Spicy & $\mathbf{1 0 1}$ & 63 & 36 \\
\hline Reasonable Price & $\mathbf{1 2 1}$ & 54 & 25 \\
\hline Translation & $\mathbf{1 0 4}$ & 59 & 37 \\
\hline Bearers & $\mathbf{1 0 7}$ & 63 & 30 \\
\hline
\end{tabular}

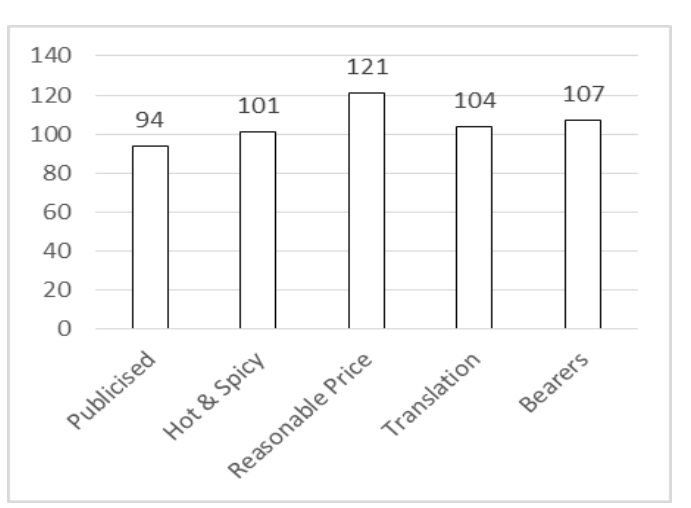

Fig. 8. Willingness to visit Malaysian restaurants.

Table VI and Fig. 8 show that more than $50 \%$ of the respondents are willing to try Malaysian restaurants if the restaurant is publicized, if the food is hot and spicy, if the price is reasonable, if menu cards have clear explanations and bearers speaking good Tamil/ English are available.

\section{H. Identifying the Target Market}

$\mathrm{H}_{0}$ : "There is no significant difference between the perceptions of the different age groups with respect to the taste of Malaysian food."

TABLE VII: AGE AND PERCEPTION TOWARDS TASTING MALAYSIAN FOOD

\begin{tabular}{|l|l|l|l|l|l|}
\hline Age & $N$ & Mean & S.D & $F$ & $P$ \\
\hline $15-25$ & 54 & 2.26 & 0.894 & 2.061 & $\mathbf{0 . 0 8 7}$ \\
\cline { 1 - 4 } $26-35$ & 72 & 1.79 & 0.821 & & \multirow{2}{*}{$\boldsymbol{H}_{\mathbf{0}}$ accepted } \\
\cline { 1 - 3 } $36-45$ & 29 & 1.93 & 0.842 & & \\
\cline { 1 - 3 }-60 & 36 & 1.92 & 1.105 & & \\
\hline$>60$ & 9 & 1.89 & 1.269 & & \\
\hline
\end{tabular}

$\mathrm{H}_{0}$ : "There is no significant difference between the perception of the male and female respondents with respect to the taste of Malaysian food"

TABLE VIII: GENDER AND PERCEPTION TOWARDS TASTING MALAYSIAN

\begin{tabular}{|l|l|l|l|l|l|}
\hline Gender & $N$ & Mean & S.D. & $F$ & $P$ \\
\hline MalE & 109 & 2.00 & 0.903 & 0.337 & $\mathbf{0 . 5 6 2}$ \\
\cline { 1 - 4 } Female & 91 & 1.92 & 0.969 & & $\boldsymbol{H}_{\mathbf{0}}$ accepted \\
\hline
\end{tabular}

$\mathrm{H}_{0}$ : "There is no association between marital status and the readiness to try Malaysian food"

\begin{tabular}{|c|c|c|c|c|c|c|}
\hline \multirow{2}{*}{\multicolumn{2}{|c|}{ Marital Status }} & \multicolumn{3}{|c|}{ Trying Malaysian Food } & \multirow{2}{*}{$\begin{array}{l}\text { Chi } \\
\text { Sq. } \\
\end{array}$} & \multirow[t]{2}{*}{$P$} \\
\hline & & Yes & No & Total & & \\
\hline \multirow[t]{3}{*}{ Married } & Count & 59 & 48 & 107 & \multirow[t]{9}{*}{3.931} & \multirow{9}{*}{$\begin{array}{l}0.047 \\
H_{0} \\
\text { rejected }\end{array}$} \\
\hline & Row \% & 55.1 & 44.9 & 100.0 & & \\
\hline & Column \% & 48.0 & 62.3 & 53.5 & & \\
\hline \multirow[t]{3}{*}{ Single } & Count & 64 & 29 & 93 & & \\
\hline & Row \% & 68.8 & 31.2 & 100.0 & & \\
\hline & Column \% & 52.0 & 37.7 & 46.5 & & \\
\hline \multirow[t]{3}{*}{ Total } & Count & 123 & 77 & 200 & & \\
\hline & Row \% & 61.5 & 38.5 & 100.0 & & \\
\hline & Column \% & 100 & 100.0 & 100.0 & & \\
\hline
\end{tabular}

$\mathrm{H}_{0}$ : "There is no association between occupation and readiness to try Malaysian food"

TABLE X: OCCUPATION AND READINESS TO TASTE MALAYSIAN FOOD

\begin{tabular}{|c|c|c|c|c|c|c|}
\hline \multirow{2}{*}{\multicolumn{2}{|c|}{ Occupation }} & \multicolumn{3}{|c|}{$\begin{array}{l}\text { Readiness to try Malaysian } \\
\text { Food }\end{array}$} & \multirow[t]{2}{*}{ Chi Sq. } & \multirow[t]{2}{*}{$P$} \\
\hline & & Yes & No & Total & & \\
\hline \multirow{3}{*}{$\begin{array}{l}\text { Gover } \\
\text { nment }\end{array}$} & No. & 7 & 4 & 11 & \multirow[t]{27}{*}{8.223} & \multirow{27}{*}{$\begin{array}{l}H_{0} \\
\text { accepted }\end{array}$} \\
\hline & $\mathrm{R} \%$ & 63.6 & 36.4 & 100 & & \\
\hline & $\mathrm{C} \%$ & 5.7 & 5.2 & 5.5 & & \\
\hline \multirow{3}{*}{$\begin{array}{l}\text { Non - } \\
\text { Gover } \\
\text { nment }\end{array}$} & No. & 30 & 25 & 55 & & \\
\hline & $\mathrm{R} \%$ & 54.5 & 45.5 & 100 & & \\
\hline & $\mathrm{C} \%$ & 24.4 & 32.5 & 27.5 & & \\
\hline \multirow[t]{3}{*}{ IT } & No. & 54 & 26 & 80 & & \\
\hline & $\mathrm{R} \%$ & 67.5 & 32.5 & 100.0 & & \\
\hline & $\mathrm{C} \%$ & 43.9 & 33.8 & 40.0 & & \\
\hline \multirow{3}{*}{$\begin{array}{l}\text { Busi } \\
\text { ness }\end{array}$} & No. & 2 & 3 & 5 & & \\
\hline & $\mathrm{R} \%$ & 40.0 & 60.0 & 100.0 & & \\
\hline & $\mathrm{C} \%$ & 1.6 & 3.9 & 2.5 & & \\
\hline \multirow{3}{*}{$\begin{array}{l}\text { Profes } \\
\text { sional }\end{array}$} & No. & 12 & 12 & 24 & & \\
\hline & $\mathrm{R} \%$ & 50.0 & 50.0 & 100.0 & & \\
\hline & $\mathrm{C} \%$ & 9.8 & 15.6 & 12.0 & & \\
\hline \multirow{3}{*}{$\begin{array}{l}\text { Retire } \\
\text { d }\end{array}$} & No. & 0 & 1 & 1 & & \\
\hline & $\mathrm{R} \%$ & .0 & 100 & 100.0 & & \\
\hline & $\mathrm{C} \%$ & .0 & 1.3 & .5 & & \\
\hline \multirow{3}{*}{$\begin{array}{l}\text { Stu } \\
\text { dent }\end{array}$} & No. & 16 & 5 & 21 & & \\
\hline & $\mathrm{R} \%$ & 76.2 & 23.8 & 100.0 & & \\
\hline & $\mathrm{C} \%$ & 13.0 & 6.5 & 10.5 & & \\
\hline \multirow{3}{*}{$\begin{array}{l}\text { Unem } \\
\text { ployed }\end{array}$} & No. & 2 & 1 & 3 & & \\
\hline & $\mathrm{R} \%$ & 66.7 & 33.3 & 100.0 & & \\
\hline & $\mathrm{C} \%$ & 1.6 & 1.3 & 1.5 & & \\
\hline \multirow[t]{3}{*}{ Total } & No. & 123 & 77 & 200 & & \\
\hline & $\mathrm{R} \%$ & 61.5 & 38.5 & 100.0 & & \\
\hline & $\mathrm{C} \%$ & 100 & 100 & 100.0 & & \\
\hline
\end{tabular}


The objective of this study was to derive a formula for success of Malaysian restaurants in Chennai. The first step towards this goal is identifying a target market by segmenting the Chennai market on the basis of gender, age, marital status and occupation. The data was tested by using statistical tools namely Chi-Sq. and ANOVA.

\section{Inference}

TABLE XI: RESULTS OF HYPOTHESIS TESTING

\begin{tabular}{|l|l|l|l|l|}
\hline Factors & Test employed & $\begin{array}{l}P \\
\text { Value }\end{array}$ & $H_{0}$ & Inference \\
\hline $\begin{array}{l}\text { Age and } \\
\text { Malaysian } \\
\text { food }\end{array}$ & ANOVA & 0.087 & Accepted & $\begin{array}{l}\text { No difference } \\
\text { among } \\
\text { different age } \\
\text { groups }\end{array}$ \\
\hline $\begin{array}{l}\text { Gender \& } \\
\text { Malaysian } \\
\text { food }\end{array}$ & ANOVA & 0.562 & Accepted & $\begin{array}{l}\text { No difference } \\
\text { among the two } \\
\text { genders }\end{array}$ \\
\hline $\begin{array}{l}\text { Marital } \\
\text { status and } \\
\text { Malaysian } \\
\text { food }\end{array}$ & Chi-Sq. & 0.047 & Rejected & $\begin{array}{l}\text { Association } \\
\text { exists between } \\
\text { marital status } \\
\text { and the } \\
\text { readiness to try } \\
\text { Malaysian } \\
\text { food. }\end{array}$ \\
\hline $\begin{array}{l}\text { Occupation } \\
\text { and } \\
\text { Malaysian } \\
\text { food }\end{array}$ & Chi-Sq. & 0.313 & Accepted & $\begin{array}{l}\text { No association } \\
\text { between } \\
\text { occupation and } \\
\text { readiness to try } \\
\text { Malaysian } \\
\text { food }\end{array}$ \\
\hline
\end{tabular}

The researcher finds that most of the respondents irrespective of their age, gender and occupation are willing to try Malaysian food. But the Chi-Sq. test run in order to test the association between the marital status and the readiness to taste Malaysian food showed that there is an association between the marital status of the respondent and the readiness to taste Malaysian food. Un-married people are more eager to taste Malaysian food than the married respondents. This can be understood from Table IX which shows that out of 107 married respondents only 59 were ready to try Malaysian food but out of 93 un-married respondents 64 were ready to try Malaysian food.

\section{J. Most Wanted Factors in a Malaysian Restaurant}

In order to find out the factors that customers look out for in a Malaysian restaurant, Factor test is applied. The KMO and Bartlett's test was employed to examine the validity of the Factor test. Since the significance value is lesser than 0.05 (0.000) as shown in Table XII the Factor test is valid.

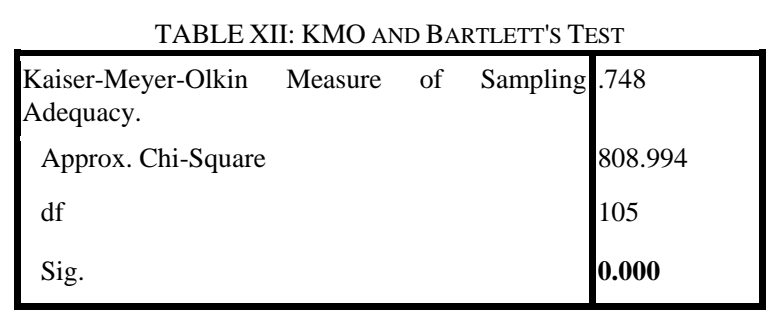

The respondents were asked to give their opinion about 16 factors under three categories namely, Food, Ambience and Staff qualities, which they look out for in a Malaysian restaurant. The responses were analyzed by employing Factor test and the results categorized the factors into four new groups on the basis of the level of influence in the decision making. The most important factors that a customer looks out for in a restaurant is the restaurant ambience including pleasant music, air conditioning, sophisticated interiors, adequate space and staff with neat appearance. Food look, aroma, quantity and variety in menu follow next. The least sought out factors include price, time and taste.

These results clearly explains the character of Chennai population. Once they decide to go to a Malaysian restaurant they would definitely demand a stylish place where they can have a different type of dining experience with good looking food with a great aroma. They are not concerned about the price charged or the time taken for the service since they are prepared to spend good amount of money and time in search of a different and new dining experience. They are ready to appreciate any taste that the Malaysian heritage offers.

\begin{tabular}{|l|l|l|l|l|l|l|}
\hline \multicolumn{7}{|c|}{ Total Variance Explained } \\
\hline Factor & $\begin{array}{l}\text { Initial Eigen } \\
\text { Values }\end{array}$ & $\begin{array}{l}\text { Extraction Sums } \\
\text { of Squared } \\
\text { Loadings }\end{array}$ & \multicolumn{2}{l|}{$\begin{array}{l}\text { Rotation Sums of } \\
\text { Squared Loadings }\end{array}$} \\
\cline { 2 - 7 } & Total & $\begin{array}{l}\text { \% of } \\
\text { Variance }\end{array}$ & Total & $\begin{array}{l}\text { \% of } \\
\text { Variance }\end{array}$ & Total & $\begin{array}{l}\text { \% of } \\
\text { Variance }\end{array}$ \\
\hline 1 & 4.325 & 28.831 & 4.325 & 28.831 & 2.402 & 16.016 \\
\hline 2 & 1.525 & 10.166 & 1.525 & 10.166 & 2.345 & 15.636 \\
\hline 3 & 1.345 & 8.964 & 1.345 & 8.964 & 1.968 & 13.118 \\
\hline 4 & 1.203 & 8.020 & 1.203 & 8.020 & 1.681 & 11.210 \\
& & & & & & \\
\hline
\end{tabular}

\begin{tabular}{|c|c|c|c|c|}
\hline \multirow[b]{2}{*}{ Factors } & \multicolumn{4}{|c|}{ Components and \% of Variance } \\
\hline & $1(28.83 \%)$ & $2(10.166 \%)$ & $3(8.964 \%)$ & $4(8.020 \%)$ \\
\hline $\begin{array}{l}\text { Music } \\
\text { Air condition } \\
\text { Interiors } \\
\text { Space } \\
\text { Staff } \\
\text { appearance }\end{array}$ & $\begin{array}{l}0.744 \\
0.728 \\
0.583 \\
0.577 \\
0.570\end{array}$ & & & \\
\hline $\begin{array}{l}\text { Food look } \\
\text { Food aroma } \\
\text { Food menu } \\
\text { Food quantity }\end{array}$ & & $\begin{array}{l}0.839 \\
0.793 \\
0.579 \\
0.493\end{array}$ & & \\
\hline $\begin{array}{l}\text { Staff language } \\
\text { Food quality } \\
\text { Staff service }\end{array}$ & & & $\begin{array}{l}0.718 \\
0.663 \\
0.611\end{array}$ & \\
\hline $\begin{array}{l}\text { Price } \\
\text { Service time } \\
\text { Taste }\end{array}$ & & & & $\begin{array}{l}0.852 \\
0.653 \\
0.424\end{array}$ \\
\hline
\end{tabular}

\section{FINDINGS}

The major findings of the study include:

- Malaysian restaurants and Malaysian food is unpopular 
in Chennai.

- Majority of the Chennai population has never tasted Malaysian food but they have an open mind towards tasting Malaysian food if offered.

- Name of the restaurant plays a significant role in helping customers identify it with Malaysia.

- The Chennai population is completely ignorant of the availability of restaurants that offer Malaysian food.

- Effective popularizing strategies must be designed and implemented to create awareness about the Malaysian restaurants among the population of Chennai.

- There is no difference in the attitudes of men and women belonging to different age groups and employed in different occupations with respect to the readiness to try Malaysian food.

- Bachelors and spinsters are more eager to try Malaysian food than married people.

- Hygienic environment, Tamil / English association, posh look and attractive food would contribute to the success of a Malaysian restaurant in Chennai.

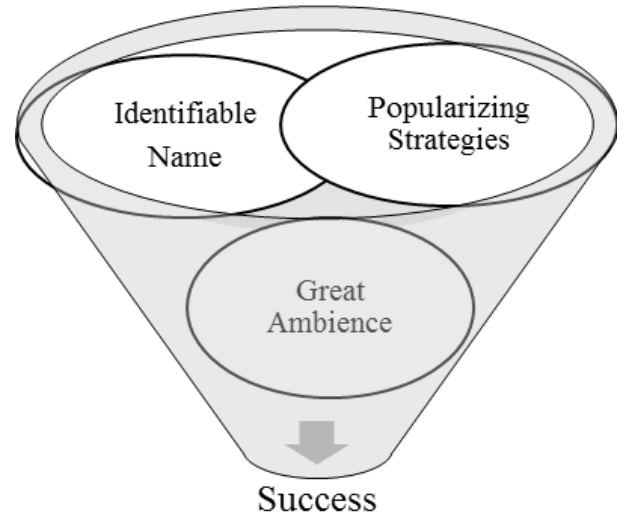

Fig. 9. Secret of success.

\section{CONCLUSION}

Chennai is a land of countless opportunities especially with respect to the restaurant business. Best example for this is the growth and popularity of Chinese fast food centers in every nook end corner of the city. Foreign food chains like KFC, Mc Donalds, Marry Brown have also reaped huge profits from the Chennai branches. Malaysian restaurants too could enjoy a share of the Chennai market if such restaurants are named with care and popularized adequately. The entire Chennai population can be targeted on but special offers, discount packages and customized marketing strategies can be adopted for the bachelors and spinsters of Chennai. The software companies usually throw parties to their employees where Malaysian food can be offered in order to delight the un-married youth working in such organizations. Once the Malaysian food is popularized, the Chennai crowd will automatically be attracted towards such restaurants. Tamil / English must be used in naming the restaurant and explaining the dishes. Bearers who speak good Tamil / English must be appointed in order to make the customers feel more comfortable. Serving appealing food in a posh and stylish manner with hygienic environment would definitely yield to the success of Malaysian restaurants in Chennai. Success of
Malaysian food in Chennai would also motivate the people from Chennai to visit Malaysia adding to the tourism income of Malaysia. In short the researcher finds that name, popularity and ambience are the three mantras for the success of Malaysian restaurants in Chennai.

\section{REFERENCES}

[1] G. Anga and D. R. Singh, "Marketing strategies and practices in Indian and Multinational fast food franchises - An Empirical Analysis," PIJMR, vol. 2, no. 2, pp. 29-32, July 2009.

[2] K. Skellernda and K. Gronhang, "Chinese food retailers positioning strategies and their influence on their buying behavior," Asia Pacific Journal of Marketing and Logistics, vol. 22, no. 2, pp. 196-209, June 2007.

[3] V. B. Masilamani and D. Sundaram, "A study on influencing factors impacting consumers food choice with respect to ready to eat segment in southern India," International Journal of Research in Commerce and Management, vol. 3, no. 2, pp. 91-96, Feb. 2012.

[4] V. G. Sumitha, "Factors influencing the buying behavior of organized retail consumers: A study on food and general stores in Vishakapatnam, India," Indian Journal of Marketing, vol. 1, no. 3, pp. 23-33, Dec. 2012.

[5] W. J. Phillips, A. Asperin, and K. Wolfe, "Investigating the effect of country image and subjective knowledge on attitudes and behaviours. U.S. upper mid westerners intentions to consume Korean food and visit Korea," International Journal of Hospitality Management, vol. 32, pp. 49-58, March 2013.

[6] U. Dinakaran, "A study on the franchised restaurants as a business model for franchisees," International Journal of Research in Commerce and Management, vol. 4, no. 2, pp. 107-111, Feb. 2013.

[7] R. Vinayak and A. Bhatia, "Outbound Indian tourists' perception of Singapore tourism - A lesson for India," International Journal of Research in Commerce and Management, vol. 4, no. 3, pp. 14-21, March 2013.

[8] S. Sipahi, "Expanding operations in the fast food industry under uncertain market conditions," International Journal of Trade Economics and Finance, vol. 1, no. 1, pp. 74-79, June 2010.

[9] H. Han and C. Jeong, "Multi dimensions of patrons' emotional experiences in upscale restaurants and their role in loyalty formation," International Journal of Hospitality Management, vol. 32, pp. 59-70, Sept 2013

[10] J. Ha and S. Jang, "Variety seeking in restaurant choice and its drivers," International Journal of Hospitality Management, vol. 32, pp. 155-168, June 2013.

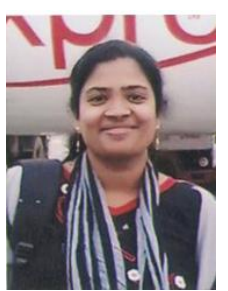

Charlet Christina Rajakumari R. was born in Chennai, Tamilnadu on May 10, 1981. Having completed higher secondary in commerce in the year 1998 in Sacred Heart Matriculation Higher Secondary School, she pursued her under-graduation and post-graduation in Commerce in Madras Christian College, Tambaram, Tamilnadu in the year 2003. She started her teaching career in the Department of Commerce, in MCC. She completed master in Philosophy in the year 2005 in the Alagappa University. She is currently pursuing Ph.D. in the topic "A Study on the Impact of the Dining Industry in the Status of Chennai".

She is currently working in the Department of Commerce, Madras Christian College as an assistant professor. She is associated with various committees in the college. Paper presentations in many International Conferences within India and abroad stand to her credit. Her research articles have been published in research journals with high impact factor. Her contributions to the field of study in 2013 were "Emotional Intelligence of the Employees of Hotel Savera" published in Training and Development Journal, Bhuvaneshwar, India and "Students Behaviour towards Foreign Food Chains - A Study in Colleges Across Chennai" presented and published in the International Conference on Tourism and Hotel Management", Colombo, Srilanka. She is an active researcher and is interested in studies relating to the hospitality industry in Chennai.

Ms. Charlet was awarded funding for a research project on "Transformational Role of Women in Preserving Ecology through Green Consumerism" by the United Board for Christian Higher Education in Asia during 2012-2013. 